\title{
Value aggregation of pine (Araucaria angustifolia) nuts agro-industrial waste by cellulose extraction
}

Agregação de valor de resíduos agroindustriais do pinhão (Araucaria angustifolia) por extração de celulose

Valor agregado de residuos agroindustriales de jatropha (Araucaria angustifolia) por extracción de celulosa

Received: 07/28/2021 | Reviewed: 07/31/2021 | Accept: 08/05/2021 | Published: 08/10/2021

Silma de Sá Barros

ORCID: https://orcid.org/0000-0002-8748-1526 Federal University of Amazonas, Brazil E-mail: engenharia.silma@hotmail.com Wanison André Gil Pessoa Jr ORCID: https://orcid.org/0000-0001-5951-8566 Federal Institute of Amazonas, Brazil E-mail: wanison.junior@ifam.edu.br

Américo Cruz Júnior

ORCID: https://orcid.org/0000-0001-7443-8871 Federal University of Santa Catarina, Brazil E-mail: americo.cruz@ufsc.br

Zeane Vieira Borges

ORCID: https://orcid.org/0000-0003-0885-7239 Federal University of Santa Catarina, Brazil E-mail: zeaneufpa@gmail.com

Cláudio Michel Poffo

ORCID: https://orcid.org/0000-0001-6270-3121 Federal University of Santa Catarina, Brazil E-mail: claudio.poffo@ufsc.br

Diogo Machado Regis

ORCID: https://orcid.org/0000-0003-4269-1981 Federal University of Santa Catarina, Brazil E-mail: diogoregis11@hotmail.com

Flávio Augusto de Freitas

ORCID: https://orcid.org/0000-0001-7940-4910 Amazon Biotechnology Center, Brazil E-mail: freitas.flavio@yahoo.com.br

Lizandro Manzato

ORCID: https://orcid.org/0000-0003-4940-9555 Federal Institute of Amazonas, Brazil E-mail: lizandro@ifam.edu.br

\begin{abstract}
Araucaria (Araucaria angustifolia) is a tree species found in the Southeast and South of Brazil. It is also known as Brazilian pine, presenting fruits of high acceptance. However, its processing generates by-products that are little used. Thus, this work aimed to extract and characterize the cellulose obtained from the pinion husk, as well as to evaluate the contents of ash, lignin, cellulose and $\alpha$-cellulose in its composition. The raw material and the extracted cellulose were characterized by X-ray fluorescence analysis (XRF), X-ray diffraction (XRD), Fourier transform infrared spectroscopy (FTIR) and thermogravimetric analysis (TGA). As for the contents of chemical composition detected, the husks showed $1.6 \%$ ash, $7 \%$ extractives, $34 \%$ lignin and 55\% cellulose, being $46 \% \alpha$-cellulose and $9 \%$ hemicellulose. It was observed by XRD that the removal of amorphous materials resulted in a gain of crystallinity (from 19 to $33 \%$ ). Proving the efficiency of the extraction, the characterization of the cellulose obtained was shown to be of high purity, since the main band of the lignin (FTIR) and the amorphous materials of the cellulosic sample (TGA) disappeared. Finally, this work shows that the pinion bark is a rich source of cellulose, making it possible to obtain nanocrystals.
\end{abstract}

Keywords: Pine nut husks; Cellulose extraction; Value aggregation.

\section{Resumo}

Araucária (Araucaria angustifolia) é uma espécie arbórea encontrada nas regiões Sudeste e Sul do Brasil. É também conhecido como pinho brasileiro, apresentando frutos de alta aceitação. Porém, seu processamento gera subprodutos que 
são pouco utilizados. Assim, este trabalho teve como objetivo extrair e caracterizar a celulose obtida da casca do pinhão, bem como avaliar os teores de cinzas, lignina, celulose e $\alpha$-celulose em sua composição. A matéria-prima e a celulose extraída foram caracterizadas por análise de fluorescência de raios X (XRF), difração de raios X (XRD), espectroscopia de infravermelho por transformada de Fourier (FTIR) e análise termogravimétrica (TGA). Quanto aos teores de composição química detectados, as cascas apresentaram 1,6\% de cinzas, 7\% de extrativos, 34\% de lignina e 55\% de celulose, sendo $46 \%$ de $\alpha$-celulose e $9 \%$ de hemicelulose. Foi observado pelo XRD que a remoção dos materiais amorfos resultou em ganho de cristalinidade (de 19 a 33\%). Comprovando a eficiência da extração, a caracterização da celulose obtida mostrou-se de alta pureza, uma vez que a banda principal da lignina (FTIR) e os materiais amorfos da amostra celulósica (TGA) desapareceram. Por fim, este trabalho mostra que a casca do pinhão é uma fonte rica em celulose, possibilitando a obtenção de nanocristais.

Palavras-chave: Cascas de pinhão; Extração de cellulose; Agregação de valor.

\section{Resumen}

Araucaria (Araucaria angustifolia) es una especie de árbol que se encuentra en el sureste y sur de Brasil. También se le conoce como pino brasileño, presentando frutos de alta aceptación. Sin embargo, su procesamiento genera subproductos poco utilizados. Así, este trabajo tuvo como objetivo extraer y caracterizar la celulosa obtenida de la cáscara del piñón, así como evaluar los contenidos de ceniza, lignina, celulosa y $\alpha$-celulosa en su composición. La materia prima y la celulosa extraída se caracterizaron mediante análisis de fluorescencia de rayos X (XRF), difracción de rayos X (XRD), espectroscopia infrarroja por transformada de Fourier (FTIR) y análisis termogravimétrico (TGA). En cuanto a los contenidos de composición química detectados, las cáscaras presentaron 1,6\% de ceniza, 7\% de extractos, 34\% de lignina y $55 \%$ de celulosa, siendo $46 \%$ de $\alpha$-celulosa y $9 \%$ de hemicelulosa. Se observó mediante XRD que la eliminación de materiales amorfos dio como resultado una ganancia de cristalinidad (del 19 al 33\%). Comprobando la eficiencia de la extracción, la caracterización de la celulosa obtenida se mostró de alta pureza, ya que desaparecieron la banda principal de la lignina (FTIR) y los materiales amorfos de la muestra celulósica (TGA). Finalmente, este trabajo demuestra que la corteza del piñón es una rica fuente de celulosa, lo que permite la obtención de nanocristales.

Palabras clave: Cascarilla de piñón; Extracción de celulosa; Agregación de valor.

\section{Introduction}

Araucaria (Araucaria angustifolia) is a species of tree found in Southeast and South Brazil, known as Brazilian pine, of the Araucariaceae family, it is a long-lived species, native to the Atlantic forest of Brazil, the species has 20 to $50 \mathrm{~m}$ in height (E. da Silva, de Lima, de Andrade, \& Brown, 2019; Montagna et al., 2019; Peralta et al., 2016). This species has a fruit called pinecones, which is a set of pine nuts ripening between the months of April to June. This fruit is one of the main sources of food for some native animals, also widely used in the field of medicine and drugs (Peralta et al., 2016; Santos et al., 2018).

Pine nuts are made up of $91.75 \%$ carbohydrates, $58.8 \%$ cellulose, $19.38 \%$ lignin, also have values of $1.89 \%$ fats, $1.27 \%$ proteins, and vitamin C (Babich et al., 2019; Daudt et al., 2017). This fruit is widely used for the production of bread, soups, and even alcoholic beverages typical of the indigenous peoples of the southern region of South America (Henríquez et al., 2008). After processing the fruit for use in the aforementioned areas, the peels are generated as a by-product. This agroindustrial waste is normally discarded in the environment, and its application is a major problem to be solved due to the large amount generated during processing (De Freitas et al., 2018; Peralta et al., 2016; Zortéa-Guidolin et al., 2017).

According to IBGE, 2018, the production of pine nuts was 9.3 thousand tons, where most of this production is concentrated in the southern region of Brazil. The production of this fruit becomes even more interesting because keeps Araucaria angustifolia alive, threatened with extinction since 1992 (Mantovani, Costa, \& Freitas, 2018). The use of agroindustrial by-products as a raw material or substitute ingredient in human and/or animal diets, or as a source of compounds of interest, becomes an extremely interesting alternative, since the number of nutrients present in these by-products may be similar or higher than those found in the main raw material (E. P. da Silva et al., 2020), even presenting high levels of vitamins, minerals, dietary fiber, in addition to wall compounds (lignin, cellulose, hemicellulose, among others) (Lan, Liu, \& Sun, 2011).

The use of by-products generated during the processing of pine nuts to obtain cellulose presents several advantages, such as the reduction of environmental impacts, as well as the obtaining of a product with high added value, which can be used 
as a raw material in the manufacture of paper, composites, drug, and food manufacturing. According to Oprea; Voicu, 2020 and Vanitha; Kavitha, 2020, the application of cellulose can be carried out in different areas such as drugs, food packaging, polymeric reinforcements, among others with high added value.

Cellulose is considered an important natural polymer, formed by $\beta-1,4$ glycosidic bonds, constituting about 35 to $50 \%$ of plant walls (Kale, Bansal, \& Gorade, 2018). Its production in the paper and cellulose industry occurs mainly from planted forests, where $85.57 \%$ comes from eucalyptus and $14.19 \%$ from pine woods (ABRAF, 2013). Therefore, the use of agroindustrial by-products as a raw material in obtaining cellulose, becomes an extremely viable alternative, adding value and developing manufactured products that directly impact socioeconomic indices. Thus, this research has the objective of extracting and characterizing the cellulose from the pine nut husks.

\section{Methodology}

\subsection{Lignocellulosic material}

Pine nuts were collected in the city of Lages, State of Santa Catarina, Brazil, Latitude: -27.8167, Longitude: -50.3264 $27^{\circ} 49^{\prime} 0^{\prime \prime}$ South, $50^{\circ} 19^{\prime} 35^{\prime \prime}$ West. The husks were washed and dried in an oven at a temperature of $70^{\circ} \mathrm{C}$. Afterwards, the husks were ground in the mill (ACD LAB TE-650/1) for $4 \mathrm{~h}$ and passed through a 45 mesh sieve.

\subsection{Materials}

Reagents used: ethanol (> 95\% vol, Vetec); sulfuric acid (> 97\%, Nuclear); sodium chlorite (> 80\%, Sigma-Aldrich); glacial acetic acid (> 99.85\%, Nuclear) and sodium hydroxide P.A (Dinâmica).

\subsection{Assessments of cellulose content and extraction}

\section{Ash percentage}

To identify the ash percentage we used the method of TAPPI, 2007, where the crucibles were weighed before adding the ground pine nut husks to get to know the mass of the crucibles. $3 \mathrm{~g}$ of the ground sample was added and dried in crucibles, later inserted in the muffle at $600{ }^{\circ} \mathrm{C}$ for $4 \mathrm{~h}$. At the end, the crucibles were weighed to constant weight to calculate their percentage.

\section{Extractive percentage}

In order to find out the percentage of extractive that the sample presents, the methodology of (TAPPI, 1997) was used, where, in a paper cartridge, $4 \mathrm{~g}$ of the dry sample was added, in a $500 \mathrm{~mL}$ flask, $150 \mathrm{~mL}$ of ethanol was added. the material in soxhlet, remaining for $4 \mathrm{~h}$, later the alcohol from the balloon was recovered in a rotaevaporator and the material from the cartridge was dried to constant weight.

\section{Lignin percentage}

In order to find out the percentage of lignin that the sample presents, the methodology (TAPPI, 2011), was as The evaluation of lignin follows: first $1 \mathrm{~g}$ of the sample without extractive was used, the sample was added to a porcelain mortar with $8.5 \mathrm{~mL}$ of sulfuric acid $(72 \%)$ (w/w) and macerated for 15 minutes and kept in digestion for 24 hours, then the digested material was placed in a glass flask together with $153 \mathrm{~mL}$ of distilled water. Then, the flask with the contents was placed in a thermal blanket, remaining for $4 \mathrm{~h}$, at a temperature of $70{ }^{\circ} \mathrm{C}$. After cooking the sample, the sample was washed and filtered with distilled water and dried in an oven until constant weight, the methodology described in (TAPPI, 2011).

Cellulose percentage and extraction 
In order to extract and quantify the percentage of cellulose, the methodology was used Kumode et al., 2017 and Pinheiro et al., 2017, $5 \mathrm{~g}$ of the sample in an Erlenmeyer with $1 \mathrm{~mL}$ of acetic acid, $5 \mathrm{~g}$ of sodium chlorite, a magnetic stirrer and $150 \mathrm{~mL}$ of distilled water, and added to a hot plate at a temperature of $70^{\circ} \mathrm{C}$ for $1 \mathrm{~h}$. After that, he placed again the same amount of $\mathrm{CH}_{3} \mathrm{COOH}$ and chlorite, remaining for another $1 \mathrm{~h}$, at the end of that hour, he added the same amount of $\mathrm{CH}_{3} \mathrm{COOH}$ and chlorite, remaining for another $2 \mathrm{~h}$. Subsequently, the Erlenmeyer flask was cooled in an ice bath. Thereafter, the contents were washed, filtered and dried to constant weight.

\section{$\alpha$-cellulose percentage}

The percentage of $\alpha$-cellulose was performed by inserting $1 \mathrm{~g}$ of the cellulose $8 \mathrm{~mL}$ of $17.5 \%$ sodium hydroxide in a porcelain mortar, where the mixture was macerated for $2 \mathrm{~min}$, then the content was washed, filtered with distilled water and dried to constant weight.

\subsection{Characterization of samples}

The samples of the fresh husks and extracted cellulose were characterized by the techniques of X-ray fluorescence (XRF), X-ray diffraction (XRD), thermogravimetric analysis (TGA) and infrared spectroscopy with Fourier Transform (FTIR).

\section{$X$-ray fluorescence}

The ground and driedff husks were analyzed by X-ray fluorescence technique (Panalytical brand equipment, model Epsilon 3-XL), using a maximum voltage of $50 \mathrm{kV}$, current of $3 \mathrm{~mA}$ and helium gas (pressure of $10 \mathrm{~atm} / 10 \mathrm{kgf} / \mathrm{cm} 2$ ).

\section{$X$-ray diffraction}

X-ray diffraction measurements were performed on a diffractometer (Bruker D2 Phase), using a copper anode and nickel filter $(\mathrm{CuK} \alpha)$, where fresh and cellulose samples (powder form) were inserted into a sample holder of acrylic, using scanning range $2 \theta=10$ to $60^{\circ}$, step $0.02^{\circ}$, and $5 \mathrm{~s} /$ step $2 \theta$, operating with a power of $40 \mathrm{kV}$, and current of $30 \mathrm{~mA}$. Rietveld method (Rietveld, 1969) was applied using the program package GSAS (Von Dreele, 1994). The starting parameters were obtained on the ICSD database (Karlsruhe, 1995). Peak shapes were modeled using a modified Thompson-Cox-Hasting pseudo-Voigt function that takes into account line broadening due to instrumental effects, small crystallite size, and microstrain (Stephens, 1999). Thermal parameters were assumed to be isotropic. Background, scale factors, and sample position shift parameters were refined before the structural parameters' refinement.

Knowing the crystallinity of cellulose is of paramount importance. Thus, to calculate the Crystallinity Index (CI), equation 1 was used (Segal, Creely, Martin, \& Conrad, 1959), where the crystalline part of the material is represented by the height of the highest peak in the diffractogram and the amorphous part of the material that refers to the amorphous halo. The Crystallinity Index (CI) is the difference between these two intensities, divided by the intensity of the most intense peak.

$$
C I(\%)=\frac{I_{\text {arm }} \text { Iam }}{I_{\text {as }}} \times 100
$$

where $I_{011}$ is the maximum intensity of the peak located in $2 \theta=22.3^{\circ}$ (plane 011 ) and $I_{a m}$ is the intensity of the amorphous halo. Fourier Transform Infrared Spectroscopy (FTIR)

For the FTIR analysis an attenuated reflectance spectrophotometer (FTIR-ATR Cary 630 - Agilent) was used. The analyzed spectra were in the range from 4,000 to $650 \mathrm{~cm}$-1, with a resolution of $8 \mathrm{~cm}-1$ with 128 scans per sample. Thermogravimetric analysis (TGA) 
To perform the thermal analysis, a thermal analyzer (Shimadzu, model TGA-50) was used. The analysis was carried out with a heating rate of $10^{\circ} \mathrm{C} / \mathrm{min}$, starting from room temperature up to $700^{\circ} \mathrm{C}$ in a nitrogen atmosphere, using $3 \mathrm{~g}$ of each sample.

\section{Results and Discussions}

\section{Lignocellulosic material content}

From the chemical characterization, it was found that the pine nut husk showed $1.6 \%$ ash, $7 \%$ extracts, $34 \%$ lignin, and $55 \%$ cellulose, of which $46 \%$ is $\alpha$-cellulose and $9 \%$ de hemicellulose. These percentages demonstrated that this by-product is a potential source for the extraction of cellulose, adding value to the waste from the culture of pine nuts in southern Brazil. The husks also present significant values of lignin (34\%), that has several applications, from the generation of energy in the industrial sector to the production of cosmetics as sunscreens (Lobosco, Silva, Pereira, Carneiro, \& Andrade, 2020; Yang, Yan, Chen, Lee, \& Zheng, 2007). It is extremely important to note that the percentage of cellulose obtained (55\%) is associated to the cellulose yield that the extraction method used was able to achieve.

When comparing the values obtained with those of the study by JACINTO et al., 2017 that used pine husks in the production of wood pellets, it is possible to observe contents with close values (Table 1). It is also observed that the cellulose content in the pine nut husks is much higher than that found in other agro-industrial residues such as soybean husks, banana pseudostem, passion fruit peels and açaí.

Table 1: Various percentages found in other waste.

\begin{tabular}{|c|c|c|c|c|c|c|}
\hline \multirow{2}{*}{ Raw materials } & \multicolumn{5}{|c|}{ Content $(\% \mathrm{~m} / \mathrm{m})$} & \multirow{2}{*}{ Reference } \\
\hline & Ash & Extractive & Lignin & Cellulose & $\alpha$-cellulose & \\
\hline Pine nut husk & 1.6 & 7 & 34 & 55 & 46 & This work \\
\hline Pine nut husk & 2.5 & 7.56 & 41 & 58.8 & - & $\begin{array}{c}\text { Jacinto et al., } \\
2017\end{array}$ \\
\hline Soybean husk & - & - & 7.78 & 40.64 & - & $\begin{array}{c}\text { Robles } \\
\text { Barros et al., } \\
2020\end{array}$ \\
\hline Banana pseudostem & - & 4.25 & - & 23.82 & - & $\begin{array}{c}\text { Meng et al., } \\
2019\end{array}$ \\
\hline Passion fruit peels & - & - & 36.18 & 28.58 & - & $\begin{array}{c}\text { Wijaya et al., } \\
2017\end{array}$ \\
\hline Açaí seeds & 1.01 & 4.48 & 24.36 & 45.49 & - & $\begin{array}{c}\text { Barros et al., } \\
2021\end{array}$ \\
\hline
\end{tabular}

Source: Authors.

In Table 1, we can pay attention to the percentages of extracted cellulose in relation to other agro-industrial residues, as it is evident that the percentage of extracted cellulose is higher than other residues, being higher than passion fruit, banana and açaí peels, because the more cellulose, better for the purpose of the research and its applications. 


\section{X-ray fluorescence (XRF)}

With the results of the XRF analysis of the raw material (ground pine nut husks) it was observed that the residue is rich in Potassium (K; 89.89\%), followed by chlorine $(\mathrm{Cl})$, which may be related to soil and water present where the plant is located, and small percentages of phosphorus $(\mathrm{P})$, iron $(\mathrm{F})$, silicon $(\mathrm{Si})$ and others (Table 2).

Table 2: Elemental analysis of pine nut husks (fresh sample).

\begin{tabular}{ccccccccc}
\hline Elements & K & Cl & P & Ag & Fe & Si & Rb & Others \\
\hline$\%(\mathbf{m} / \mathbf{m})$ & 89.89 & 5.77 & 2.65 & 0.81 & 0.22 & 0.21 & 0.15 & 0.29 \\
\end{tabular}

Source: Authors.

It is noteworthy that this analysis highlights the chemical components of the material studied, which can interfere with the results of ash content when oxides are formed, for example, resulting in $\mathrm{CO}_{2}$ adsorption. The percentages of these elements can vary depending on the climate, temperature, soil, and region where it is inserted.

In Table 2, it is worth highlighting the percentage of potassium present in the fiber, knowledge about these levels can also help to guide the waste application. For example, residues with high potassium $(\mathrm{K})$ content, as presented by pine nut husk, have been applied to obtain heterogeneous catalysts for biodiesel production (de S. Barros et al., 2020; Mendonça, Machado, et al., 2019; Mendonça, Paes, et al., 2019).

\section{X-ray diffraction (XRD)}

Fig. 1 shows the XRD patterns for the ground pine nut husk in natura (black curve) and extracted cellulose (blue curve) samples. The red curve shown the simulated pattern by using the FindIt program (Woo, Lee, Kim, \& Lee, 2004) with the crystallographic data obtained from the Crystallographic Information File (CIF) - code 4114382.

Figure 1: XRD patterns for the husk (black curve), extracted cellulose (blue curve) samples, and simulated pattern (red curve) using CIF code file 4114382.

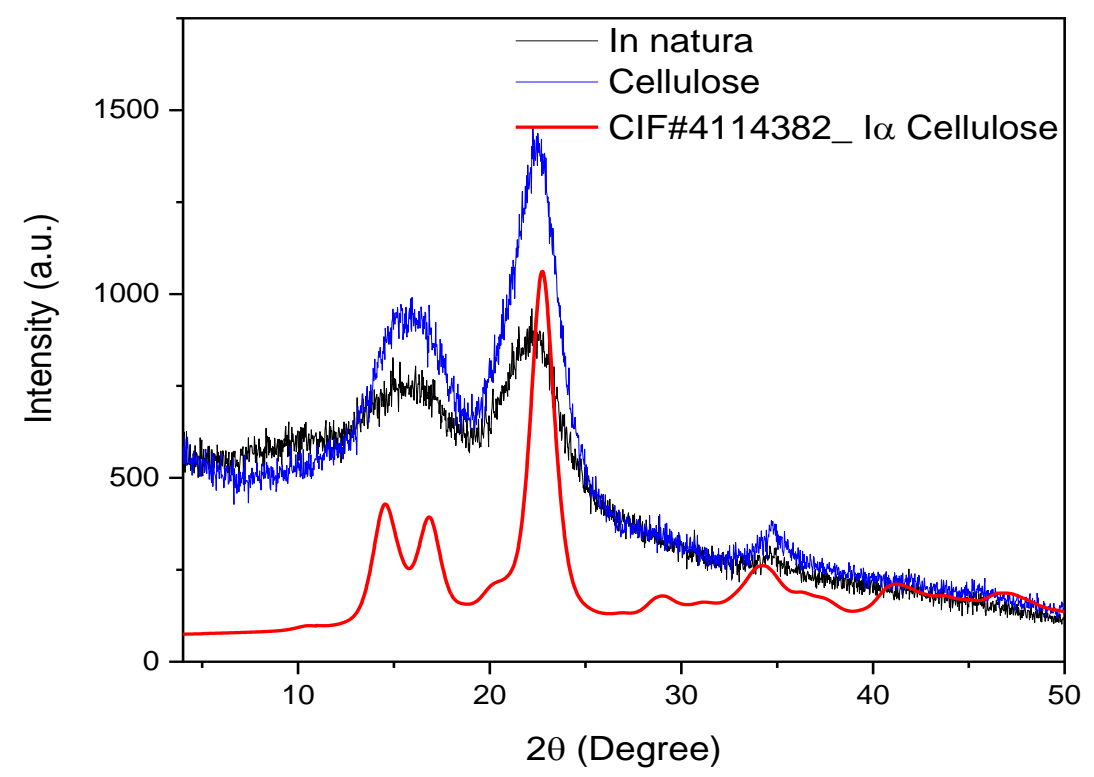

Source: Authors. 
In Figure 1 we can make a comparison of the fresh sample with cellulose in relation to the input Cif, we can observe the intensity of the peaks between $20^{\circ}$ and $30^{\circ}$, showing more intensity for the cellulose sample, which is related to the increase in crystallinity.

Both patterns have shown two peaks broaden halos between $2 \theta \approx 10^{\circ}-30^{\circ}$. In addition, a low-intensity diffraction peak located at $2 \theta \approx 34^{\circ}$ is observed. Furthermore, a main amorphous halo centered at $2 \theta \approx 15.7^{\circ}$ can be identified in both pattern samples. Using the Ehrenfest equation $(2 R \sin \theta=1.23 \lambda)$ (Manzato, Trichês, De Souza, \& De Oliveira, 2014) an interatomic distance of $\mathrm{R} \approx 6.9 \AA$ was calculated for a second neighbor husk. Is important to note that the peak located at $2 \theta \approx 34^{\circ}$ and both amorphous halos have their intensity increasing when compared with the XRD pattern of in natura sample. This suggests that both samples have a natural crystalline cellulose phase dispersed in an amorphous matrix. For the cellulose sample, the crystallinity is increased, showing the partial success of the cellulose extraction adopted method.

The patterns shown in Fig. 1 were compared with the CIF file $n^{\circ} 4114382$ of triclinic symmetry (S.G. P 1, $\left.n^{\circ} 1\right)$ give in the Crystallography Open Database for I $\alpha$ cellulose (red curve), where a good agreement can be observed. This CIF was used as a structural model for the Rietveld Refinement with the following initial parameters: $a=10.400(10) \AA, b=6.717(6) \AA$, $\mathrm{c}=5.962(7) \AA, \alpha=80.37(5)^{\circ}, \beta=118.08(5)^{\circ}$ and $\gamma=114.80(5)^{\circ}$. Fig. 2 shows the Rietveld refinement for the extracted cellulose sample.

Figure 2: Experimental (open circles) and simulated (red curve) XRD pattern of the extracted cellulose sample. The background (green curve) as well the residual line (blue curve) are also shown

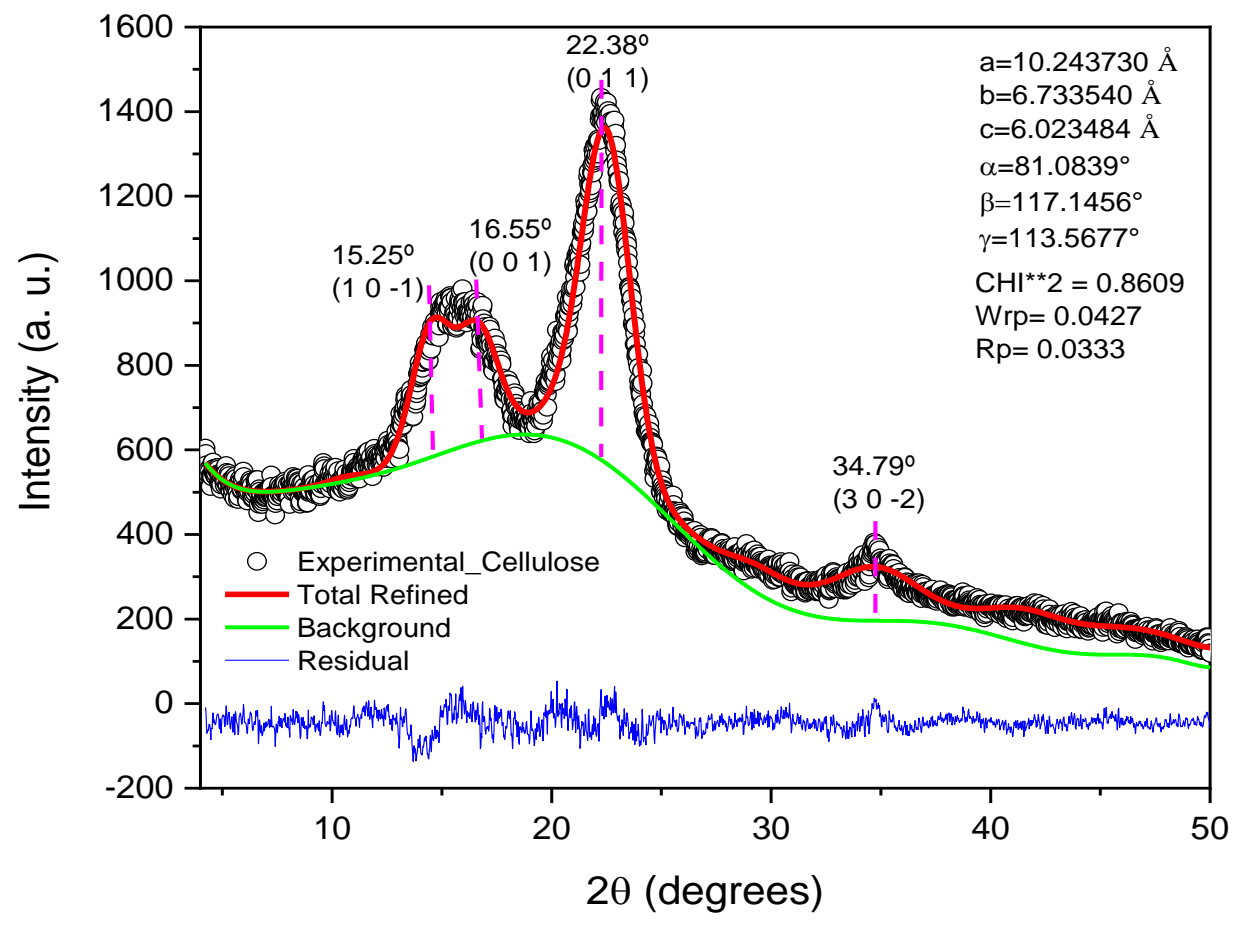

Source: Authors.

In Figure 2 we can see a good agreement between the experimental and simulated patterns can be observed for the extracted cellulose sample. The refinement was done using Chebyshev function twelve order for background fit. Table 3 summarizes the data obtained from refinements. 
Table 3: Structural parameters obtained from refinements of in pine nut husks and extracted cellulose.

\begin{tabular}{ccc}
\hline Parameters & Pine nut husks & Cellulose \\
\hline $\mathrm{a}(\AA)$ & $10.16(8)$ & $10.24(3)$ \\
$\mathrm{b}(\AA)$ & $6.73(3)$ & $6.73(3)$ \\
$\mathrm{c}(\AA)$ & $6.04(1)$ & $6.02(3)$ \\
$\alpha\left(^{\circ}\right)$ & $81.92(7)$ & $81.08(3)$ \\
$\beta\left(^{\circ}\right)$ & $116.99(5)$ & $117.14(5)$ \\
$\gamma\left({ }^{\circ}\right)$ & $112.71(6)$ & $113.56(7)$ \\
$\mathrm{Vol}\left(\AA^{3}\right)$ & $339.62(0)$ & $338.61(0)$ \\
$\mathrm{R}_{\mathrm{wp}}(\%)$ & 4.27 & 3.84 \\
$\mathrm{R}_{\mathrm{p}}(\%)$ & 3.33 & 2.94 \\
\hline
\end{tabular}

Source: Authors.

The Table 3 shows cell sizes after refinements, it is noteworthy that the results are like those found in the literature.

The average crystallite size was calculated using the Scherrer equation (Phys., Chem., 2018) by the most intense peak located at about $2 \theta \sim 22.3^{\circ}$ of XRD patterns. For the extracted cellulose sample, we obtained an average crystallite size of 11 $\mathrm{nm}$ for I $\alpha$ cellulose. The apparent crystallinity percentage (C) was estimated using the eq. (1). We observed $19 \%$ and $33 \%$ of crystallinity for the husks and extracted cellulose, respectively. For the cellulose sample, the crystallinity obtained is lower when compared to other studies (Naduparambath et al., 2018). This can be explained by the small nanocrystals obtained, resulting in low crystallinity.

\section{Fourier Transform Infrared Spectroscopy (FTIR)}

Fig. 3 shows the FTIR spectra for samples ground pine nut husk and extracted cellulose. The band found at $3310 \mathrm{~cm}^{-1}$ for the two samples corresponds to the $\mathrm{OH}$ stretching vibrations of the cellulose molecules and inter and intramolecular hydrogen bonds (Tanpichai, Biswas, Witayakran, \& Yano, 2019). Similar bands were observed in the passion fruit peels (Wijaya et al., 2017). At 2880 and $2335 \mathrm{~cm}^{-1}$, asymmetric and symmetrical C-H elongation vibrations were observed for aliphatic portions in polysaccharides attributed to cellulose components (Cheng et al., 2017; Singh, Ranawat, \& Meena, 2019). At $1630 \mathrm{~cm}^{-1}$, for the sample of the ground pine nut husk sample, a marked band was noticed and is attributed to the acetyl and uronic ester groups of the hemicelluloses or ester bonds of the lignin carboxylic groups present in the sample (Kale et al., 2018; Tanpichai et al., 2019). It was also observed that this band is not perceived in the cellulose spectra, showing a good removal of amorphous materials from the sample. The band located at $1240 \mathrm{~cm}^{-1}$ is attributed to compounds of ester, ether, or phenol that are corresponding elements present in lignin in the spectrum of the raw material. And, at $1110 \mathrm{~cm}^{-1}$, a band attributed to the anti-symmetric elongation of the bridge of the COC groups of the cellulose structure - $\beta(1,4)$ glycosidic bonds (Singh et al., 2019; Tanpichai et al., 2019). Therefore, these changes and disappearances of the bands confirm the complete removal of lignin from the raw material, showing the efficiency of the method applied for this purpose and generating cellulose. 
Figure 3: Infrared spectra of fresh (green curve) samples and extracted cellulose (black curve).

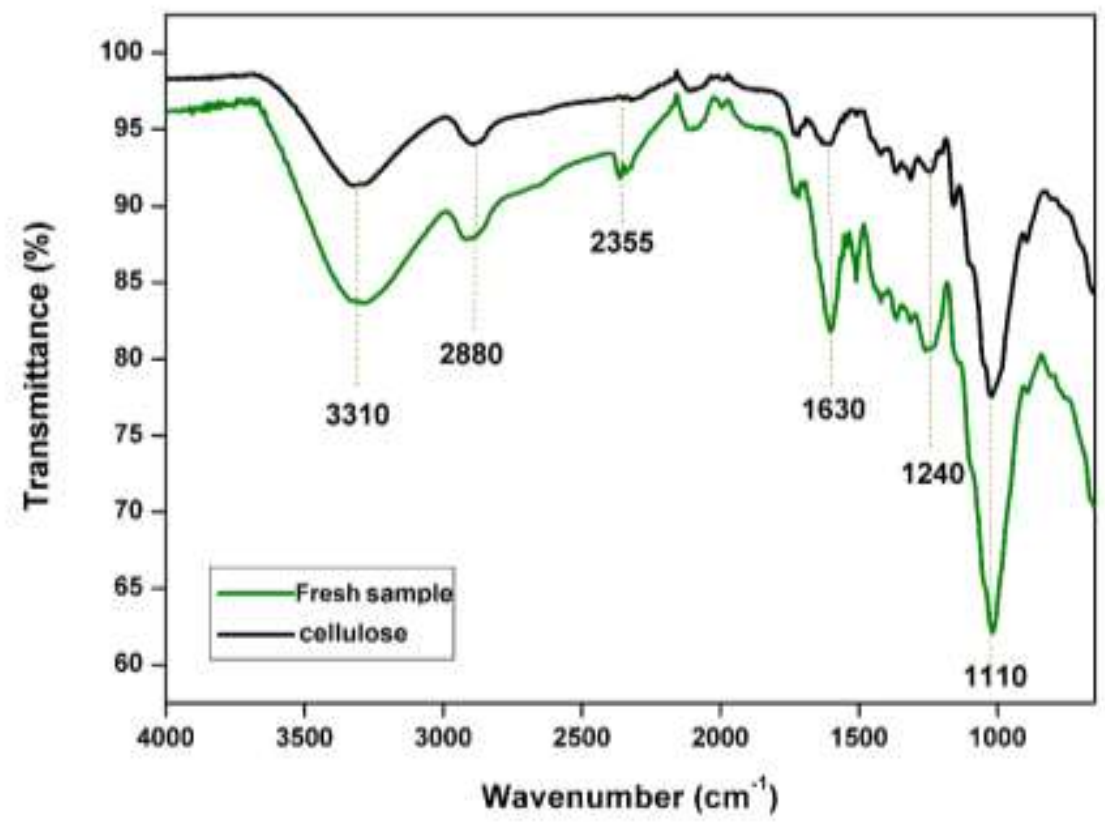

Source: Authors.

In Figure 3 of the spectra, we can turn our attention to the disappearance of some of the bands for the cellulose sample in relation to the fresh sample, mainly at 1630 and $1240 \mathrm{~cm}^{-1}$, showing removal of lignin after treatment.

\section{Thermogravimetric analysis}

Analyzing the TG and DTG curves (Fig. 4) of the cellulose obtained from the pine nuts, can be observed there was a loss of mass in three stages for the raw material and two stages of degradation for the cellulose. Up to $100{ }^{\circ} \mathrm{C}$, a loss of mass is observed due to the volatilization of water and low molecular weight compounds present on the material surface (Cheng et al., 2017;). The second degradation stage started at around $240{ }^{\circ} \mathrm{C}$ for both samples, which may be related to the beginning of depolymerization, and decomposition of the cellulose glycosidic binding units (Cheng et al., 2017). Between $280-300{ }^{\circ} \mathrm{C}$, a slight shoulder is noticed referring to the beginning of hemicellulose shedding. The dominant thermogravimetric peak was observed at $350{ }^{\circ} \mathrm{C}$ for both samples, a step related to the total decomposition of glycosidic chains by depolymerization, dehydration, and decomposition of glycosidic bonds, followed by the formation of a residue after burning (Mokhena \& John, 2020). The third stage of degradation occurred at around $460{ }^{\circ} \mathrm{C}$, where the degradation of lignin from the fresh sample occurred. This event was not observed for the cellulose sample, confirming that no lignin was found in the cellulose sample. This event was not observed for the cellulose sample, confirming that no lignin was found in the cellulose sample. This stage shows that cellulose has less thermal stability than lignin, because the lignin contains different types of bonds, making it difficult to decompose and, therefore, starting its degradation at around $420{ }^{\circ} \mathrm{C}$. Studies show that depending on the origin of the material, lignin can degrade up to $900{ }^{\circ} \mathrm{C}$ (Fauzan et al., 2018). When comparing the thermogravimetric curves of the cellulose sample with those observed by, it is possible to notice a similarity in all stages of degradation. For the fresh sample, the lower thermal instability of the material is attributed to the presence of amorphous materials in the sample, which degrade at high temperatures. Based on these results, it was noted the effectiveness of removing amorphous materials from the sample after treatment, corroborating with FTIR and XRD results that showed absence of the characteristic peak of hemicelluloses. 
Figure 4: Thermogravimetric analysis graphs: a) TG and b) DTG of pine nut husks and extracted cellulose.

(a)

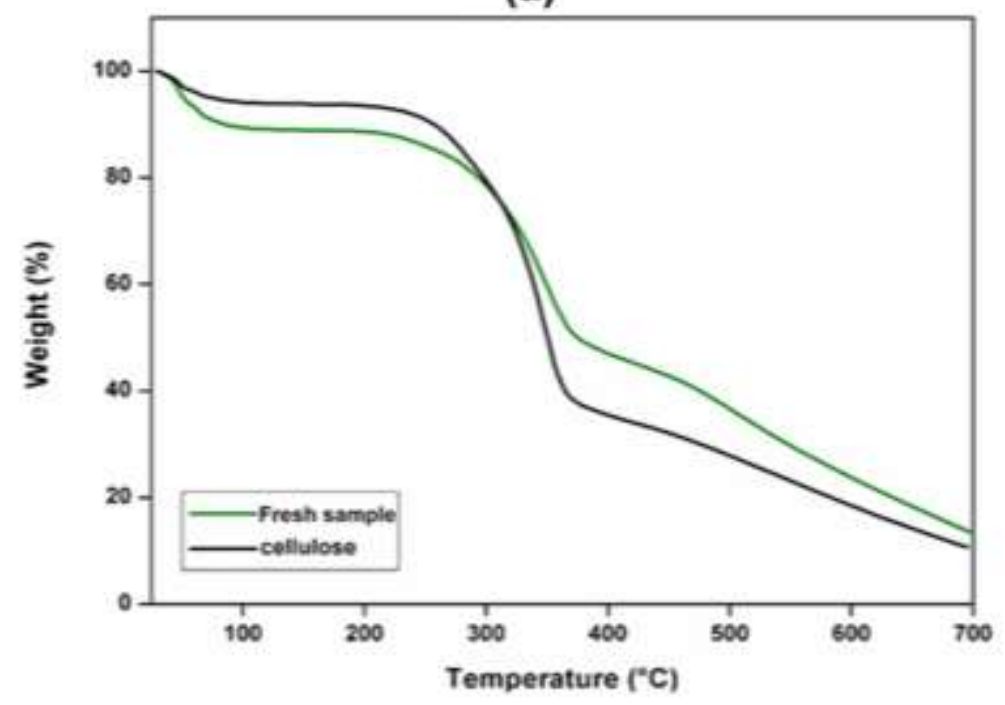

(b)

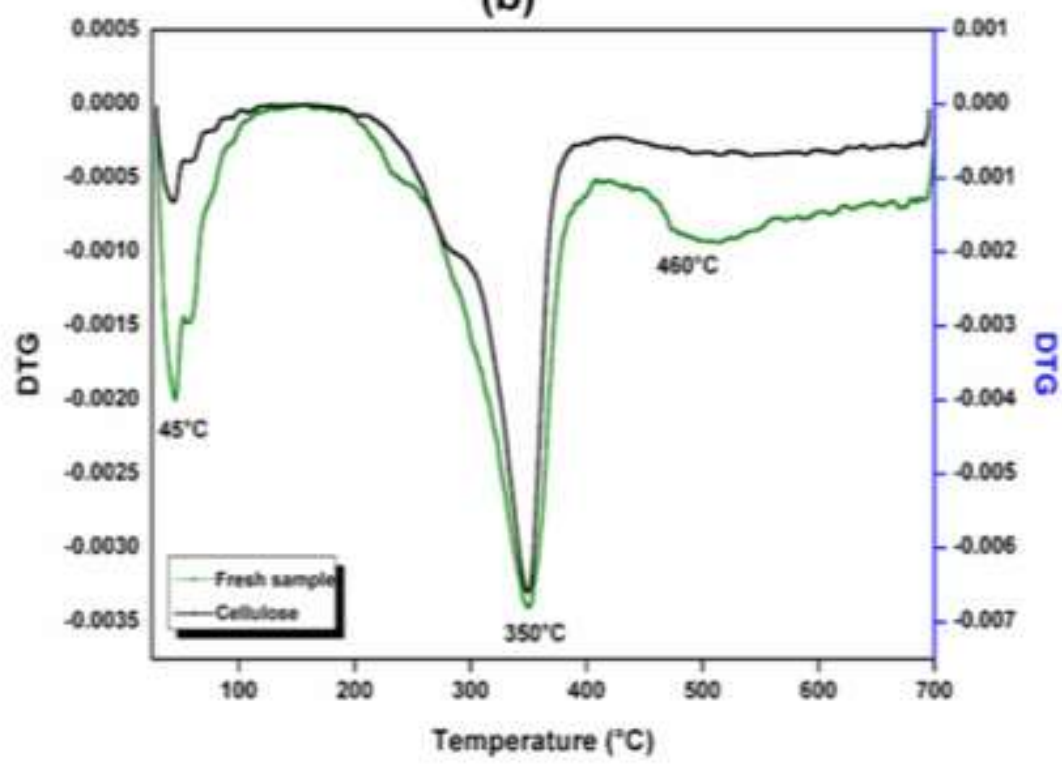

Source: Authors.

In this Figure 4 of DTG we can highlight the disappearance of some peaks, for example at a temperature of $450{ }^{\circ} \mathrm{C}$, which was not seen in the cellulose sample, showing success in the removal of amorphous materials.

\section{Conclusions}

This article highlights the great potential of this waste for cellulose extraction. The fiber yielded 55\% cellulose, a much higher value when compared to other agro-industrial residues. The husks were characterized in terms of lignocellulosic content, with $7 \%$ of extracts, $34 \%$ of lignin, $1.6 \%$ of ash and $46 \%$ of $\alpha$-cellulose and $9 \%$ hemicellulose. The characterization of cellulose by XRD, FTIR and TGA techniques showed that high purity cellulose was obtained, confirming that the methodology used removed amorphous materials, mainly lignin, from the sample, resulting in cellulose with excellent qualities, which enhances the use of this waste for this purpose. These results open the way for research based on this culture, as well as the application of other agro-industrial waste as an alternative source of cellulose. From the extracted cellulose and 
its lignocellulosic fractions evaluated, as future works we can mention the application of the fiber for composites in a polymer matrix, applying the cellulose as drug enablers, the lignin can be applied in the cosmetics sectors for sunscreens, from the cellulose can also be extracted from nanocellulose, which have a range of applicability, from the treatment of burns, applied to materials for implants, production of thin films, etc.

\section{Acknowledgment}

The authors would like to thank CAPES for financing the master's scholarship, $\mathrm{n}^{\circ} 88882.452656 / 2019-01$, to Laboratório de Materiais Amazônicos e Compósitos - LAMAC/UFAM and Laboratório de Síntese e Caracterização de Nanomateriais LSCN/IFAM.

\section{References}

ABRAF. (2013). Anuário Estatístico da ABRAF. Brasilia.

Babich, O., Dyshlyuk, L., Noskova, S., Sukhikh, S., Prosekov, A., Ivanova, S., \& Pavsky, V. (2019). In vivo study of the potential of the carbohydrate-mineral complex from pine nut shells as an ingredient of functional food products. Bioactive Carbohydrates and Dietary Fibre. https://doi.org/10.1016/j.bcdf.2019.100185

Barros, S. de S., Oliveira, E. da S., Pessoa Jr, W. A. G., Rosas, A. L. G., Freitas, A. E. M. de, Lira, M. S. de F., ... Freitas, F. A. de. (2021). Waste açaí (Euterpe precatoria Mart.) seeds as a new alternative source of cellulose: Extraction and characterization. Research, Society and Development, 10(7), e31110716661. https://doi.org/10.33448/rsd-v10i7.16661

Silva, E., de Lima, O. G., de Andrade, D. P., \& Brown, G. G. (2019). Earthworm populations in forestry plantations (Araucaria angustifolia, Pinus elliottii) and Native Atlantic forest in Southern Brazil compared using two sampling methods. Pedobiologia. https://doi.org/10.1016/j.pedobi.2018.10.002

Daudt, R. M., Sinrod, A. J. G., Avena-Bustillos, R. J., Külkamp-Guerreiro, I. C., Marczak, L. D. F., \& McHugh, T. H. (2017). Development of edible films based on Brazilian pine seed (Araucaria angustifolia) flour reinforced with husk powder. Food Hydrocolloids. https://doi.org/10.1016/j.foodhyd.2017.04.033

De Freitas, T. B., Santos, C. H. K., da Silva, M. V., Shirai, M. A., Dias, M. I., Barros, L., ... Leimann, F. V. (2018). Antioxidants extraction from Pinhão (Araucaria angustifolia (Bertol.) Kuntze) coats and application to zein films. Food Packaging and Shelf Life. https://doi.org/10.1016/j.fpsl.2017.10.006

de S. Barros, S., Pessoa Junior, W. A. G., Sá, I. S. C., Takeno, M. L., Nobre, F. X., Pinheiro, W., ... de Freitas, F. A. (2020). Pineapple (Ananás comosus) leaves ash as a solid base catalyst for biodiesel synthesis. Bioresource Technology. https://doi.org/10.1016/j.biortech.2020.123569

Henríquez, C., Escobar, B., Figuerola, F., Chiffelle, I., Speisky, H., \& Estévez, A. M. (2008). Characterization of piñon seed (Araucaria araucana (Mol) K. Koch) and the isolated starch from the seed. Food Chemistry. https://doi.org/10.1016/j.foodchem.2007.08.040

Instituto brasileiro de geografia e estatística. (2018). Produção da Extração Vegetal e da Silvicultura 2017. Rio de Janeiro: IBGE.

Jacinto, R. C., Brand, M. A., da Cunha, A. B., Souza, D. L., \& da Silva, M. V. (2017). Utilização de resíduos da cadeia produtiva do pinhão para a produção de pellets para geração de energia. Floresta. https://doi.org/10.5380/rf.v47i1.52080

Kale, R. D., Bansal, P. S., \& Gorade, V. G. (2018). Extraction of Microcrystalline Cellulose from Cotton Sliver and Its Comparison with Commercial Microcrystalline Cellulose. Journal of Polymers and the Environment. https://doi.org/10.1007/s10924-017-0936-2

Karlsruhe. (1995). ICSD - Inorganic Crystal Structure Database. Gmchin-Intitut fur Anorganishe Chemie und Fachinformationszentrum FIZ.

Kumode, M. M. N., Bolzon, G. I. M., Magalhães, W. L. E., \& Kestur, S. G. (2017). Microfibrillated nanocellulose from balsa tree as potential reinforcement in the preparation of 'green' composites with castor seed cake. Journal of Cleaner Production. https://doi.org/10.1016/j.jclepro.2017.02.083

Lan, W., Liu, C. F., \& Sun, R. C. (2011). Fractionation of bagasse into cellulose, hemicelluloses, and lignin with ionic liquid treatment followed by alkaline extraction. Journal of Agricultural and Food Chemistry. https://doi.org/10.1021/jf201508g

Lobosco, M. P. J., Silva, R. M. C. R. A., Pereira, E. R., Carneiro, E. C. da S. P., \& Andrade, A. C. dos S. (2020). The relationship between environmental education and natural sunscreens: an integrative review. Research, Society and Development, 9(6), e158963535. https://doi.org/10.33448/rsd-v9i6.3535

MANTOVANI, A., COSTA, N., \& Freitas, C. (2018). Situação Atual e Conservação das Florestas com Araucária. SEMINÁRIO SUL-BRASILEIRO SOBRE A SUSTENTABILIDADE DA ARAUCÁRIA. Passo Fundo, RS.

Manzato, L., Trichês, D. M., De Souza, S. M., \& De Oliveira, M. F. (2014). Synthesis of nanostructured SnO and SnO2 by high-energy milling of Sn powder with stearic acid. Journal of Materials Research. https://doi.org/10.1557/jmr.2013.220

Mendonça, I. M., Machado, F. L., Silva, C. C., Duvoisin Junior, S., Takeno, M. L., de Sousa Maia, P. J., ... de Freitas, F. A. (2019). Application of calcined waste cupuaçu (Theobroma grandiflorum) seeds as a low-cost solid catalyst in soybean oil ethanolysis: Statistical optimization. Energy Conversion and Management, 200(September), 112095. https://doi.org/10.1016/j.enconman.2019.112095

Mendonça, I. M., Paes, O. A. R. L., Maia, P. J. S., Souza, M. P., Almeida, R. A., Silva, C. C., ... de Freitas, F. A. (2019). New heterogeneous catalyst for 
biodiesel production from waste tucumã peels (Astrocaryum aculeatum Meyer): Parameters optimization study. Renewable Energy, 130, 103-110. https://doi.org/10.1016/j.renene.2018.06.059

Meng, F., Zhang, X., Yu, W., \& Zhang, Y. (2019). Kinetic analysis of cellulose extraction from banana pseudo-stem by liquefaction in polyhydric alcohols. Industrial Crops and Products. https://doi.org/10.1016/j.indcrop.2019.05.025

Mokhena, T. C., \& John, M. J. (2020). Esterified cellulose nanofibres from saw dust using vegetable oil. International Journal of Biological Macromolecules. https://doi.org/10.1016/j.ijbiomac.2020.01.278

Montagna, T., Lauterjung, M. B., Costa, N. C. F. da, Bernardi, A. P., Candido-Ribeiro, R., \& Reis, M. S. dos. (2019). Guidelines for seed collection of Araucaria angustifolia (Bertol.) Kuntze: A genetic, demographic and geographic approach. Forest Ecology and Management. https://doi.org/10.1016/j.foreco.2019.02.006

Naduparambath, S., T.V., J., Shaniba, V., M.P., S., Balan, A. K., \& Purushothaman, E. (2018). Isolation and characterisation of cellulose nanocrystals from sago seed shells. Carbohydrate Polymers. https://doi.org/10.1016/j.carbpol.2017.09.088

Oprea, M., \& Voicu, S. I. (2020). Recent advances in composites based on cellulose derivatives for biomedical applications. Carbohydrate Polymers. https://doi.org/10.1016/j.carbpol.2020.116683

Peralta, R. M., Koehnlein, E. A., Oliveira, R. F., Correa, V. G., Corrêa, R. C. G., Bertonha, L., ... Ferreira, I. C. F. R. (2016). Biological activities and chemical constituents of Araucaria angustifolia: An effort to recover a species threatened by extinction. Trends in Food Science and Technology. https://doi.org/10.1016/j.tifs.2016.05.013

Phys., Chem., M. (2018). A. Vorokh, Scherrer formula: estimation of error in determining small nanoparticle size. Https://Doi.Org/10.17586/2220-8054-20189-3-364-369, (https://doi.org/10.17586/2220-8054-2018-9-3-364-369), https://doi.org/10.17586/2220-8054-2018-9-3-364-36.

Pinheiro, I. F., Ferreira, F. V., Souza, D. H. S., Gouveia, R. F., Lona, L. M. F., Morales, A. R., \& Mei, L. H. I. (2017). Mechanical, rheological and degradation properties of PBAT nanocomposites reinforced by functionalized cellulose nanocrystals. European Polymer Journal. https://doi.org/10.1016/j.eurpolymj.2017.10.026

Rietveld, H. M. (1969). A profile refinement method for nuclear and magnetic structures. Journal of Applied Crystallography. https://doi.org/10.1107/s0021889869006558

Robles Barros, P. J., Ramirez Ascheri, D. P., Siqueira Santos, M. L., Morais, C. C., Ramirez Ascheri, J. L., Signini, R., ... Alessandro Devilla, I. (2020). Soybean hulls: Optimization of the pulping and bleaching processes and carboxymethyl cellulose synthesis. International Journal of Biological Macromolecules. https://doi.org/10.1016/j.ijbiomac.2019.12.074

Santos, C. H. K., Baqueta, M. R., Coqueiro, A., Dias, M. I., Barros, L., Barreiro, M. F., ... Leimann, F. V. (2018). Systematic study on the extraction of antioxidants from pinhão (araucaria angustifolia (bertol.) Kuntze) coat. Food Chemistry. https://doi.org/10.1016/j.foodchem.2018.04.057

Segal, L., Creely, J. J., Martin, A. E., \& Conrad, C. M. (1959). An Empirical Method for Estimating the Degree of Crystallinity of Native Cellulose Using the X-Ray Diffractometer. Textile Research Journal. https://doi.org/10.1177/004051755902901003

Silva, E. P. da, Dias, L. G., Marot, P. P., Goulart, G. A. S., Freitas, F. A., \& Damiani, C. (2020). Fatty acid and chemical composition of the seed and the oil obtained from marolo fruit (Annona crassiflora Mart.). Research, Society and Development. https://doi.org/10.33448/rsd-v9i9.6670

Stephens, P. W. (1999). Phenomenological model of anisotropic peak broadening in powder diffraction. Journal of Applied Crystallography. https://doi.org/10.1107/S0021889898006001

Tappi. (2007). Solvent extractives of wood and pulp ( Proposed revision of T $204 \mathrm{~cm}-97$ ). Tappi.

Technical Association of Pulp and Paper Industry. T204 cm-97. Solvent extractives of wood and pulp., TAPPI test methods $§(1997)$.

Technical Association of the Pulp and Paper Industry. (2011). TAPPI T 222: Acid-insoluble lignin in wood and pulp. In TAPPI test methods. https://doi.org/10.1023/a:1019003230537

Vanitha, R., \& Kavitha, C. (2020). Development of natural cellulose fiber and its food packaging application. Materials Today: Proceedings. https://doi.org/10.1016/j.matpr.2020.07.029

Von Dreele, A. C. L. and R. B. (1994). GSAS: General structure analysis system. LAUR 86-748.

Wijaya, C. J., Saputra, S. N., Soetaredjo, F. E., Putro, J. N., Lin, C. X., Kurniawan, A., ... Ismadji, S. (2017). Cellulose nanocrystals from passion fruit peels waste as antibiotic drug carrier. Carbohydrate Polymers. https://doi.org/10.1016/j.carbpol.2017.08.004

Woo, K. G., Lee, J. H., Kim, M. H., \& Lee, Y. J. (2004). FINDIT: A fast and intelligent subspace clustering algorithm using dimension voting. Information and Software Technology. https://doi.org/10.1016/j.infsof.2003.07.003

Yang, H., Yan, R., Chen, H., Lee, D. H., \& Zheng, C. (2007). Characteristics of hemicellulose, cellulose and lignin pyrolysis. Fuel. https://doi.org/10.1016/j.fuel.2006.12.013

Zortéa-Guidolin, M. E. B., Demiate, I. M., Godoy, R. C. B. de, Scheer, A. de P., Grewell, D., \& Jane, J. lin. (2017). Structural and functional characterization of starches from Brazilian pine seeds (Araucaria angustifolia). Food Hydrocolloids. https://doi.org/10.1016/j.foodhyd.2016.08.022 